\title{
KIND OF ANNIVERSARY
}

\author{
Károly Pintér
}

\section{UTOPIA - Approaches to a book with many faces}

Utopos me General from not island made island.

Alone I of-lands all without philosophy

State philosophical I-have-formed for-mortals.

Willingly I-impart my-things, not not-willingly I-accept better-ones.

(A Specimen of Utopian Poetry in Thomas More's "word-forword translation") ${ }^{1}$

According to Nietzsche, 'only that which has no history can be defined'. If he is right, then the concept of utopia is certainly one among the countless others the definition of which is to be deemed hopeless from the start. The term itself looks back upon a history of almost five hundred years but the underlying idea - the proposition of an ideal human community - is at least two thousand years older. In addition to the sheer historical time span, utopia has been from its inception an ambiguous concept and this inherent ambiguity seems to have been particularly vigorous, reproducing and multiplying itself in the course of the centuries to such an extent that nowadays almost any discourse on utopia is threatened to get bogged down in the quagmire of the interpretation of the very term. A perceptive reading of a large part of the literature written on the subject reveals that in many a case, the participants of a particular scholarly debate are often not even aware of the fact that

\footnotetext{
'More (1965) 25 (an 'example of Utopian poetry' in supposedly original form, transliterated and in Latin translation, was attached to the beginning of Utopia)
} 
their disagreement stems from a fundamentally different interpretation of what 'utopia' is.

The detailed investigation of the tortuous development of the concept - and the genre - would stretch the limited space of this essay. It would not be without interest, however, to focus our attention to the generic source and archetype, Thomas More's Utopia. Thanks to its pioneering character and the challenging, still provocative ideas it contains, the book has found its way to probably all major literatures and many literature and history textbooks. But its widespread popularity and certain well-known interpretative clichés often obscure the complexity and ambiguity of More's work. A closer examination of this multiplicity of meaning may help us to see how the subsequent development of the utopian genre - with its numerous turns and traps - has been determined and influenced by More's work. 


\section{RECEPTION AND CRITICAL VIEWS}

The word 'Utopia' was invented to designate an imaginary island and as the title of a literary piece. ${ }^{2}$ More's work (published first in 1516 in Louvain, Flanders) achieved instant success and became an outstanding best-seller of its time: the various editions both in Latin and in all the important Western European languages of the age ${ }^{3}$ ensured that Utopia gained wide international popularity and reached not only the privileged few educated in Latin but the literate public as well, the proportion of which was growing with the advent of Reformation.

If we attempt to look for a reason for this considerable success in critical opinions, we may be surprised to find some very different reactions and interpretations, which, on the other hand, can help in highlighting some of the problems surrounding Utopia.

The virtuous poet:

Philip Sidney, the noted Elizabethan courtier, traveler and writer, praised More's Utopia in the following words in his Apologie for Poetrie (published posthumously in 1595):

But euen in the most excellent determination of goodnes, what Philosophers counsell can so redily direct a Prince, as the fayned Cyros in Xenophon, or a vertuous man in all fortunes, as Aeneas in Virgil, or a whole Common-wealth, as the way of Sir Thomas Moores Eutopia? I say the way, because where Sir Thomas Moore erred, it was the fault of the man and not of the Poet, for that way of patterning a Common-wealth was

\footnotetext{
${ }^{2}$ The word is a Latinized form of a Greek compound: ou + topos, meaning 'no-place'. More, however, hid a pun in 'utopia': the Latinized prefix $u$ - can stand for the Greek eu- as well as ou- and thus 'utopia' may also mean 'good-place'.

${ }^{3}$ Until 1600, Utopia was published in Latin in 11(!) different editions all over Europe (Louvain, Paris, Basel, Florence, Cologne, Wittenberg), with the remarkable exception of England, where the first Latin edition appeared only in 1663 . The book was soon translated into several vernaculars as well: before the 16th century was out, three English, two French, two Dutch, one German and one Italian translation were published as well.(Gibson 3-4) The lack of an early Latin edition in England has not been adequately accounted for by scholarship; the most obvious explanation - that is, the possible political risks More would have incurred by the publication during his political career and his being a Catholic martyr and thus a persona non grata in Protestant England afterwards - is undercut by the fact that the three 16th-century English editions were published under the rule of Edward (1551), Mary (1556) and Elisabeth (1597), respectively, among widely different political circumstances, and yet they managed to promote Utopia to one of the popular and prominent books of the age in Ralph Robinson's classic translation.
} 
most absolute, though hee perchaunce hath not so absolutely perfourmed it. $^{4}$

Sidney's enthusiasm is justified by the underlying idea of his tract, that is, to argue in favour of the importance and utility of 'poetry' (at that time still designating literature in general) in the spirit of the Horatian idea 'to teach and delight'. ${ }^{5}$ For him, Utopia was an outstanding example of the best qualities of 'poetry': it entertains the reader and at the same time persuades him or her about the best moral values not by abstract argumentation but by describing a convincing example, being therefore superior to both philosophy and history. This understanding was essentially in line with the dominant Humanist reading of More as the author of a great Christian allegory. More's fellow humanists - Erasmus, Jerome Busleiden and others - praised the book as an persuasive embodiment of true Christian virtues and practices but neglected (accidentally or deliberately) those aspects of Utopia which were difficult to harmonize with the teaching of the Church: religious tolerance, marriage of priests, euthanasia, lack of private property, etc. What is novel about Sidney's evaluation is the justification he provides for this discrepancy by making a distinction between artistic intention and its realization: even with the noblest intentions, a fallible man is prone to commit errors and thus More's perfect commonwealth inevitably has its defects; yet it doesn't disparage his merit of attempting to sketch up such an ideal social organization. Thus Sidney attaches a primarily pragmatic value - teaching ethics through entertainment - to Utopia without stopping to consider the actual ideas of the book, treating them as if they were absolutely unambiguous and unquestionably positive.

\section{The Proto-communist:}

The long-standing authority of this interpretation was challenged by 19 thcentury Marxists, who focused on exactly those aspects of the book which - being incongruent with the "Christian commonwealth"-type reading - were blithely tossed aside as mere "human errors". Marx and Engels in their Communist Manifesto already cited the famous "sheep-parable" of Book I to illustrate how market-

\footnotetext{
${ }^{4}$ Sidney $18-19$ (italics mine)

${ }^{5} \mathrm{Cf}$. Horace 73: "The aim of the poet is either to benefit, or to amuse, or to make his words at once please and give lessons of life."

"These placid creatures, which used to require so little food, have now apparently developed a raging appetite, and turned into man-eaters. Fields, houses, towns, everything goes down their throats." (More (1965) 46)
} 
oriented agriculture destroyed the medieval village, and pointed out the astuteness of More's economic prescience. Later Karl Kautsky devoted a whole book to More, ${ }^{7}$ in which he opted for a literal reading of Book II, with special regard to the communal arrangement of life, work and property, and hailed More as a political visionary, an early advocate of communist ideals. This reading later became a schoolroom commonplace in the Soviet Union and the satellite states of the Eastern Bloc.

The man of faith and political philosopher:

The single most influential work in 20th-century More-criticism has been R.W. Chambers' acclaimed biography, in which he evaluated Utopia with the following words:

[F]ew books have been more misunderstood than Utopia. ... When a sixteenth-century Catholic depicts a pagan state founded on reason and philosophy, he is not depicting his ultimate ideal. Erasmus tells us that More's object was 'to show whence spring the evils of States, with special reference to the English State, with which he was most familiar'. The underlying thought of Utopia always is, With nothing save Reason to guide them, the Utopians do this, and yet we Christian Englishmen, we Christian Europeans...!

In his wake, a whole critical school sprang up, which was characterized by one of its representatives as "humanistic" or "Catholic". 9 Their argument essentially follows Chambers' line of thought: Book II is a demonstration of the way a good society can be created with the proper application of reason alone; such a society, however, is not More's own ideal because it lacks the guidance of true revelation, and that explains those aspects of Utopia contrary to Christian principles. It is thus a demonstration of the power of natural reason and an implicit criticism of contemporary European practices but also intended to show the limits of mere reason. ${ }^{0}$ Such an approach locates the core of the work in the serious politicalethical content it offers and considers it largely as a theoretical treatise expressed in a metaphorical form. Another current of the same school admonishes the advocates of the above-mentioned approach for their failure to appreciate the original and

\footnotetext{
${ }^{7}$ See Kautsky

${ }^{8}$ Chambers 118,121

${ }^{9}$ See Logan 8, Elliott 26; both quote the eminent More-scholar, Edward L. Surtz S.J., editor of the Yale critical edition of More's Complete Works.

${ }^{10}$ For one of the most substantial arguments in favour of this reading, see Duhamel.
} 
radical nature of the ideas put forward by More and suggests that Utopia is above all an outstanding piece of Renaissance political theory.

The literary artist:

The post-war boom of literary criticism with its contesting approaches and opinions has also affected the understanding of Utopia: a new group of critics drew attention to the defects of earlier simplistic readings or sweeping generalizations by shifting the emphasis on the satirical, that is, the actual literary nature of Utopia: the numerous puns and learned jokes; the question of More's attitude towards his own creation, the admirer of the island, Raphael Hythlodaeus; the parallels Utopia shows with classical satirical works ${ }^{12}$ are all to be accounted for to form a balanced view of the full meaning of the work. Some of them has gone as far as suggesting that Utopia is a mere jeu d'esprit, in fact an anti-utopia, a parody of the ideas of Hythlodaeus and similar dreamy-eyed enthusiasts. ${ }^{13}$ These new critical observations, however, have not eliminated but rather multiplied the problems surrounding the book.

\section{SOURCES AND INFLUENCES}

More, of course, did not create his island out of the void: criticism has pointed to various probable sources of inspiration and discerned the influence of several traditions. The most obvious of these is the classical heritage: More received the best humanist education of his time in Oxford and London, made close friends with Erasmus during the latter's extended visits in England and joined his efforts to render the great works of ancient Greek authors available by translating Lucian into Latin. A comparison between Utopia and Lucian's fantastic voyages clearly shows that they undoubtedly served as a structural model. ${ }^{14}$ The other famous archetype is of course Plato's Republic, to which More makes explicit references at several

\footnotetext{
${ }^{11} \mathrm{~A}$ recent and excellent example of this approach is Logan; this book also contains a detailed and balanced evaluation of the various dominant currents of More-criticism (4-18)

${ }^{12}$ See e.g. "The Shape of Utopia" in Elliott 25-49

${ }_{14}^{13}$ See e.g. C.S. Lewis 169

14 " $[\mathrm{I}] \mathrm{t}$ is a curious fact that in More's lifetime he was probably more widely read as the translator of Lucian than the author of Utopia. By 1535 his translations of Lucian had appeared in fourteen editions compared to only six editions of Utopia." (Branham 23) This excellent study demonstrates in great detail that one of the dialogues by Lucian which More translated into English, Menippus Goes to Hell, shows close structural similarities to Utopia.
} 
points, ${ }^{15}$ and his style and use of rhetorical figures shows that he has learned a lot from the classical masters. ${ }^{16}$

On the other hand - which might be less conspicuous to the majority of readers -, medieval attitudes, thought and literature also form an organic part of More's work. He belonged to the first generation of English Humanists; the earliest pioneers, John Colet, William Grocyn, Thomas Linacre and others, were probably no more than ten years his senior and although they all acted as his teacher at one time, More later became their intimate friend. Their claim to being 'Humanists' rests not only on their classical Greek scholarship but also on a passionate interest in contemporary problems of doctrine and the Church. Ali of them except More were churchmen, but More's early biographers emphasized his religious devotion, his austere personal tastes and his strong attraction to holy orders. ${ }^{7}$ Accordingly, there are several aspects of Utopia which show more affinity with the Middle Ages then the Renaissance. Chambers referred to a number of features which would have almost certainly made More look like a conservative man of his age. Utopia is

${ }^{15}$ See e.g. the short, playful poem More inserted before the beginning of his book (ostensibly written by Hythlodaeus' nephew), in which he makes an ironic statement about the purpose of Utopia :

Utopia priscis dicta, ob infrequentiam,

Nunc civitatis aemula Platonicae,

Fortasse victrix, (nam quod illa literis

Deliniavit, hoc ego una prestiti,)

viris et opibus optimisque legibus

Eutopia merito sum vocanda nomine.

(More [1971] 4; in More [1965] 28 and 133, one can find a rather free translation:

NOPLACIA was once my name,

That is, a place where no one goes.

Plato's Republic now I claim

To match, or beat at its own game;

For that was just a myth in prose,

But what he wrote of, I became,

Of men, wealth, laws a solid frame,

A place where every wise man goes:

GOPLACIA is now my name.)

Another reference is made to the famous archetype during the debate between More and Raphael in Book I (More [1965] 57).

${ }^{16}$ For details, see e.g. McCutcheon (1977) and (1985) on More's use of litotes and Stoic paradoxes.

${ }^{17}$ Chambers $71-80$. 
essentially founded upon the Four Cardinal Virtues assigned for goodly pagans (Wisdom, Fortitude, Temperance, Justice) by medieval tradition. The organization of the island in the main resembles the monastic way of life: class distinction is absent, manual labour is considered a positive virtue for all, private property is abolished, and lifestyle is frugal, lacking all luxuries, with discipline strongly enforced by a self-governing community. ${ }^{8}$ In addition, one scholar has provided convincing proof for the similarity between Utopia and eminent Scholastics in terms of argumentation and style. ${ }^{19}$

And last but by no means least, contemporary European issues and events are both explicitly and implicitly present in the book. Perhaps the one thing all critics agree on is that Utopia is a powerful criticism of the state of early sixteenth-century Christian Europe: besides the openly political dialogue of More and Hythlodaeus in Book I, most of the satire of Book II is also implicitly directed against the exasperating reality of the age, with its ceaseless and pointless wars, selfish and tyrannical monarchs, greedy and corrupted churchmen and rampant social problems. Another obvious inspiration behind the book is the brand new experience of a widening and wondrous world full of surprises often exceeding the fancy of storytellers, resulting in a curious mingling of fantasy and reality in the common imagination. There is proof in the text for the fact that More was familiar with recent accounts of the wonders experienced by explorers of the New World. ${ }^{20}$

\section{NARRATIVE STRUCTURE}

Surveying the enormous diversity of literary, political, philosophical and historical influences on Utopia, one may well wonder how and to what extent More succeeded in moulding his disparate material into a unified artistic work. Doubts concerning the coherence of the book are further strengthened by the variety of often clashing opinions on Utopia outlined above. If we attempt to look for the

\footnotetext{
${ }^{18}$ Chambers $124-130$.

${ }^{19}$ See Duhamel.

${ }^{20}$ In Book One of Utopia, Raphael Hythlodaeus, the man who visited Utopia, is introduced to More as somebody who accompanied Amerigo Vespucci and "forced Amerigo to let him be one of the twentyfour men who were left behind in that fort. ... when Vespucci had gone, Raphael did a lot of exploring with five other members of the garrison." In this way, More skillfully gives an air of authenticity to what Hythlodaeus is going to tell, because this account is taken almost verbatim from Vespucci's own descriptions of his adventures, New World (about 1505) and Four Voyages (1507) (More [1965] 38$39,135-136)$
} 
primary cause of these disagreements, we inevitably arrive at the fictional framework within the limits of which More chose to constrain himself. Utopia is divided into two books of unequal length: Book I (B.I) is roughly half the length of Book II (B.II); in later editions, they are preceded by several letters exchanged between More, Peter Gilles (who is More's Flemish companion in B.I and another listener to Raphael Hythlodaeus' narration) and other humanist friends (the number of letters varies in different editions). B.I partly serves as a general introduction, describing the actual occasion and circumstances of the encounter between Raphael and More, and partly contains a lengthy Platonic-style debate between them, with Raphael taking the lead. It is in the course of this debate that the island of Utopia arises, and B.II is essentially Raphael's continuous, uninterrupted and unmediated monologue about this island and its inhabitants, with a very brief, almost hasty, epilogue by More.

The apparent purpose of this whole fictional apparatus is to give an air of authenticity to the otherwise quite incredible words of Raphael. More's letter to Gilles, which has been attached to later editions of the book as a kind of introduction, consists mostly of repeated statements about how carefully he strove to "repeat what Raphael told us" (29): ${ }^{21}$ he implores Gilles to reinforce the correctness of each word either from his own memory or contact Raphael himself and get him to do the proof-reading; he even asks a trivial question about the length of a certain bridge in Utopia to show: "You see, I'm extremely anxious to get my facts right" (30). Just by way of a side remark, he requests Gilles to find out the exact location of the island since "we never thought of asking, and he never thought of telling us whereabouts in the New World Utopia is" (30-31).

This letter is, however, worthy of a second, closer look. More is all too eager to present himself as a humble scribe who has no creative ambitions nor talents but they are not necessary either, since the wording, the style, the structure is not his own: "So much of it was ready made, that there was practically nothing left for me to do." (29). But in More's hands, this seemingly modest disavowal of authorship becomes a crafty excuse for any defects, stylistic or other, the 'story' (that is, Raphael's account) might possess. More plays the game perfectly straight-faced: "I only wish my scholarship and intelligence were up to the standard of my memory... any lies that I tell will be quite unintentional, for I'd much rather be thought honest than clever" (30)

All subsequent quotations are from More (1965), with page numbers given in brackets. 
This exaggerated modesty and self-effacement is, of course, one of the stylistic requirements and clichés of the Renaissance following classical examples, just as Gilles' exuberant raptures in return (this letter is addressed to Busleiden) are, who glorifies More's excellent memory, beautiful Latin style and in general "the prodigious, if not positively superhuman power of his intellect" (34). Gilles is also quick to join More's authenticity game when he makes up a 'cover story' why More could not recall the exact location of the island (More was distracted by his servant's whisper and somebody else started to cough just at the moment Raphael uttered the relevant words). But do they seriously expect their readers - originally most of them also learned humanists - to be misled by such a traditional and transparent fictional framework of false reality?

An excerpt from More's letter may be helpful in this matter. At the end of his message to Gilles, More expresses doubts whether he should or will publish his work at all. His explanation is worth quoting in full:

Tastes differ so widely, and some people are so humourless, so uncharitable, and so absurdly wrong-headed, that one would probably do far better to relax and enjoy life than worry oneself to death trying to instruct or entertain a public which will only despise one's efforts, or at least feel no gratitude for them. Most readers know nothing about literature - many regard it with contempt. Lowbrows find everything heavy going that isn't completely lowbrow. Highbrows reject everything as vulgar that isn't a mass of archaisms. Some only like the classics, others only their own works. Some are so grimly serious that they disapprove of all humour, others so half-witted that they can't stand wit. Some are so literal-minded that the slightest hint of irony affects them as water affects a sufferer from hydrophobia. Others come to different conclusions every time they stand up or sit down. Then there's the alcoholic school of critics, who sit in public houses, pronouncing ex cathedra verdicts of condemnation, just as they think fit. They seize upon your publications, as a wrestler seizes upon his opponent's hair, and use them to drag you down, while they themselves remain quite invulnerable, because their barren pates are completely bald - so there's nothing for you to get hold of.

(31-32; italics mine)

Even though his letter is on the whole ironic and insincere, we have reason to suppose that the words quoted above reflect More's own opinion about the contemporary literary situation. It is true that this position - that of the intellectual 
aristocrat, contemplating his age with a condescending satirical eye and occasional disgust - is very much in line with the fashionable humanist attitude of the times. But we should bear in mind that More was indeed not writing for "most readers", "low- or highbrows", "humourless", "half-witted" or "literal-minded" people: the language in which he chose to write, the fact that he had it published abroad, in a contemporary cultural centre of Northwestern Europe, the close affinity with classical Greek archetypes - all this strongly suggests that his audience in mind was a small and select community of erudite artist-scholars - people who can appreciate a complex work in its fullness, complete with its philosophical load, playful fantasy, learned allusions and satirical-critical edge. The underlying idea could best be understood as an intellectual game of a closed society which has its own secret rules to keep undesired intruders out. One of these tricks is to play the fool and thus fool others, as More appears to have done so already with some success: "there's a very pious theologian, who's desperately keen to visit Utopia, not in a spirit of idle curiosity, but so that he can foster the growth of Christianity ... As he wishes to do it officially, he has decided to get himself sent out there by the Pope, and actually created Bishop of Utopia. He's not deterred by any scruples about begging for preferment." (31)

This is the clearest moment in the letter when More's laughter is nearly audible behind the lines. This allusion, regardless of whether to a real or an imagined person, is a cutting quip on human ambition and human folly. More, however, who was also a lawyer, a man of practical wisdom and experience, must have known all too well that such people can be found in substantial numbers 'out there', that is, outside the circle of intellectual aristocrats. He must have also been perfectly aware of the possible dangers one exposes oneself to when taking such a radically new approach to society and religion. His work in its final form strongly suggests that, just as a seasoned professional wrestler should do, he was determined not to offer much hair for his opponents to grasp. A discerning reading of B.I of Utopia makes it clear that More the author was painstakingly careful to distance himself from Raphael, the "dispenser of nonsense".

The debate:

B.I begins the story at the beginning: More the narrator's ('More') ${ }^{23}$ voyage to Flanders, his first encounter with the stranger and Raphael's brief life story are all

\footnotetext{
${ }^{22}$ The meaning attached to the Greek-derived name 'Hythlodaeus' by Paul Turner; see More (1965) 8

$: 3$ To help distinguish between the various different references of the name, it seems justified to introduce three terms: 'More', the narrator of the whole story, 'More2', who argues with Hythlodaeus
} 
duly described. He is introduced to 'More' by Gilles as a philosopher-traveler ("He is really more like Ulysses, or even Plato." [38]), an experienced and very wise man. 'More' and Gilles are both eager to listen to his voyages and experiences in the New World but Raphael's actual account of his adventures is little more than alluded to: "My present plan is merely to repeat what he said about the laws and customs of Utopia.", says 'More' (41).

Before coming to that, however, 'More' considers it necessary to record "the conversation which led up to the first mention of that republic" (41). It is this exchange which gives the bulk of B.I and provides the narrative framework of the direct and uninterrupted description of Utopia in B.II, therefore it is of particular interest to us.

The conversation is triggered by the repeated urge of both Gilles and More the debater ('More2'): ${ }^{24}$ why does Raphael, a man of so great wisdom and practical experience, not join the service of some king in order to apply his knowledge for public benefit? Raphael, however, is quick and categorical in rejecting the idea, and, in support of his position, he offers some scathing criticism of contemporary politics: kings are more fond of war and conquest than proper peaceful government, royal councillors are too arrogant, stupid and conceited to accept anybody else's advice or opinion. As an example and illustration, he brings up England which he also visited a few years earlier and where, at the dining table of the Lord Chancellor, Cardinal Morton, ${ }^{25}$ he entered into an argument with an English lawyer.

From this point on, the narration becomes quite complicated: 'More' quotes the words of Raphael who in turn quotes a debate between himself and some others. The proper referential identity of the pronoun ' $I$ ' has thus become considerably confused, which may have been Mure's exact purpose: after all, it is certainly not without danger to criticize radically the political and social circumstances of one's own country. And Raphael is anything but restrained in his criticism during the quoted argument: he condemns the practice of hanging thieves as both exceedingly cruel and ineffective since the cause of crime - extreme poverty - remains. As to the cause of this poverty, he provides a surprisingly thorough and keen economic

and whose words are quoted by 'More', and More, the author, whose role is similar to that of a puppet master, watching the performance with a knowing smile. This system of distinction was partly inspired by Elliott, which also contains an incisive analysis of the complex narrative structure of Utopia.

${ }^{24}$ See previous note.

${ }^{25}$ Morton was More's benefactor and virtual stepfather, who raised and educated him, as a short remark of 'More2' on 57 also makes clear. This explains More's (Hythlodaeus') admiring and affectionate portrayal of hin 
analysis (which has always been a favourite with Marxist readers): the idle and wasteful lifestyle of the nobility compels them to make as much money as they can, therefore they enclose cultivated lands for raising sheep and selling the valuable wool. This practice both deprives people of their livelihood and drives food prices up. "Thus a few greedy people have converted one of England's greatest natural advantages into a national disaster. ... you create thieves, and then punish them for stealing!" (48-49) Raphael is therefore arguing strongly against the death penalty and, prompted by Morton, he even sketches up a minor 'prison-Utopia': an imaginary country (supposedly known by him), where criminals are not executed but sentenced to hard labour; if, however, they work diligently and behave well, they are treated humanely and are even allowed to move about freely during the day, wearing distinctive clothes. Thus, the lives of the criminals are saved, they do not suffer disproportionately and they even benefit the whole community.

These are radical words, which could easily become dangerous for an Englishman; but they are put into the mouth of a foreigner. At the table, everybody disagrees with him except for the wise Cardinal, whose tentative endorsement to the idea (it would be worth a trial) suddenly changes all other opinions. Thus, the political treatise becomes also a parable of servility - the original reason why Raphael has come up with the whole story.

After Raphael's long lecture, 'More2' takes up the debate again: he agrees with Raphael in what he has said, and yet tries to make him change his mind with the argument of duty; as a support, he refers to Plato in the Republic: "You know what your friend Plato says - that a happy state of society will never be achieved, until philosophers are kings, or kings take to studying philosophy. Well, just think how infinitely remote that happy state must remain if philosophers won't even condescend to give kings a word of advice!" (57)

Raphael retorts by saying that philosophers are glad to give advice and they have done so already in their works but people in power have never listened to them: "And that's doubtless what Plato meant." (57) He again provides examples, this time theoretical ones: what would the king of France say, if he were, together with his councillors, to annex new territories, and plotting all kinds of treacherous political moves, should a philosopher like Raphael advised him to stay in peace and concentrate on the better government of his own kingdom? Or what would be any king's reaction if, when considering how to make more money out of his subjects, Raphael reminded him that he rules not for his own but his subjects' benefit and therefore he should devote all his energies to the betterment of their lot? In these 
imagined exchanges between himself and the king, Raphael again cites examples taken from nonexistent lands which are both "not far from Utopia" - the name is thus mentioned twice, seemingly casually and accidentally.

'More2' reacts in an interesting way: "Frankly, I don't see the point of saying things like that, or of giving advice that you know they'll never accept. ... That sort of thing is quite fun in a friendly conversation, but at a Cabinet meeting, where major decisions of policy have to be made, such philosophizing would be completely out of place." (63) What he prefers instead is a more practical kind of philosophy which takes reality and its constraints into account and takes a step-bystep approach in advocating reform. "You must go to work indirectly. You must handle everything as tactfully as you can ... For things will never be perfect, until human beings are perfect - which I don't expect them to be for quite a number of years!" (64)

Raphael strongly disagrees: he considers such an attitude an excuse for telling lies, which is unworthy of a philosopher, and also a cowardly endorsement of blind prejudice and petrified tradition. But besides this, why are his ideas so unusual and unrealistic?

If we're never to say anything that might be thought unconventional, for fear of its sounding ridiculous, we'll have to hush up, even in a Christian country, practically everything that Christ taught. ... His doctrines have been modified by ingenious preachers - doubtless on your recommendation! 'We'll never get human behaviour in line with Christian ethics,' these gentlemen must have argued, 'so let's adapt Christian ethics to human behaviour...' But I can't see what good they've done. They've merely enabled people to sin with a clear conscience - and that's about all I could do at a Cabinet meeting.

This gradually heightening argument is crucial since it draws a clear line of distinction between 'More2' and Raphael: the former, the alter ego of the author, is shown as a well-intentioned, morally earnest but at the same time sober and realistic man, whereas the latter appears doubtless highly educated and morally upright but also a stubborn adherent of noble but irreal ideas, a man of little practical wisdom. Or, alternatively, 'More2' can be regarded with equal justification as a man of cowardly compromise, whereas Raphael champions true Christian virtues and principles with unwavering loyalty. In either case, it is Raphael who comes to the conclusion that the root of all evil in the world is private property and material 
inequality, and cites Utopia - here no longer in a fleeting remark but in an emphatic statement - as a country immensely superior to all European kingdoms by virtue of its institutions. There, with the elimination of private property, hardship and poverty have also disappeared.

'More2' continues to disagree and his counter-arguments are also surprisingly familiar:

I don't believe you'd ever have a reasonable standard of living under a communist system. There'd always tend to be shortages, because nobody would work hard enough. In the absence of a profit motive, everyone would become lazy, and rely on everyone else to do the work for him. ... there wouldn't be any respect for authority ... in a classless society.

Raphael's retort is predictable: "You're bound to take that view, for you simply can't imagine what it would be like ... But if you'd been with me in Utopia, and seen it all for yourself as I did ... you'd be the first to admit that you'd never seen a country so well organized." (67, italics mine) Such a statement naturally begs the request to introduce the famous island in detail - and 'More2' indeed does so. Abstract argument thus gives way to a supposedly practical example, communism in action - B.II follows.

\section{More and 'More' versus Raphael:}

How and in what direction does the dialogue of B.I examined above modify and reinterpret the meaning of B.II? First of all, it does not only identify but thoroughly characterize the teller of the utopian tale, Raphael Hythlodaeus, and establish him as a person whose ideas and opinions are markedly different from More's own. The careful distance created between Raphael and 'More' constitutes the primary interpretative problem for most critics: which participant should be supposed to articulate the author More's own views?

The surprisingly short conclusion may be invited in help. The work ends abruptly: 'More' (or 'More2', if you like; the distinction is no longer relevant) thanks Raphael for his interesting account, and, seeing that he is tired after so much talking, bids good-bye to him with the words that they should meet and discuss the whole thing sometime. In his heart, however, he remains unconvinced:

The laws and customs of that country seemed to me in many cases perfectly ridiculous. ... there was the grand absurdity on which their whole society was based, communism minus money. Now this in itself would 
mean the end of the aristocracy, and consequently of all dignity, splendour, and majesty, which are generally supposed to be the real glories of any nation. ... I cannot agree with everything that he said ... But I freely admit that there are many features of the Utopian Republic which I should like though I hardly expect - to see adopted in Europe.

'More' thus remains faithful to his proclaimed belief to the last; he behaves exactly as a person of authority should expect him to do: he is the defender of the status quo, the representative of practical, if unimaginative, wisdom as opposed to the devoted and radical reformer, the enthusiast, the man of dangerous neologisms Raphael Hythlodaeus. The final counter-remarks of 'More', however, appear distinctly feeble, almost downright stupid, when he is trying to oppose "splendour", "majesty" and "aristocracy" to the well-being and harmony of Utopia. More, the author, does not offer a very flattering picture of himself with these last words - if we are to take him seriously. But even without knowing that More in reality was renowned for his frugal tastes and his contempt for all kinds of luxury and "splendour", the hidden irony in these words can be perceived. He is, however, a perfect player, whose face remains straight throughout: there is no direct way to catch him out, no opportunity to grab a single lock of his hair.

If the opinions of 'More' are most probably not identical with those of More himself, is it possible then that the real raisoneur is Raphael after all? It is true that, especially in the first half of B.I, one has the impression that Raphael's words could be More's own - but one should never disregard the significance of the fact that Utopia is a piece of fiction where the island is described by a character whose name means "dispenser of nonsense" and whose occasional overheated enthusiasm as well as his complete disregard of contemporary European reality make him look comic; the punning place-names and titles in Utopia, the supplied 'utopian alphabet' and 'poem', ${ }^{26}$ the occasional surprising and humorous episodes in the description all serve as reminders that we are in the world of playful imagination, and thus the solemnity of the whole venture is constantly brought into suspicion. More's opponent wrestler, besides lacking anything to hold onto, has to watch the ground under his feet throughout.

Perhaps the most interesting attempt at clearing up the problem of "authorial intention" has been the book of J.H. Hexter, who conducted a detailed investigation

\footnotetext{
${ }^{26}$ See quote at the beginning of this essay.
} 
into the composition of Utopia. ${ }^{27}$ After a close examination of the text and various extrinsic evidence, he concluded that More wrote most of B. II (except for the end) and the general introduction of B.I first, while staying in Antwerp as part of an official trade delegation, and added the lengthy and meandering dialogue of Raphael and 'More' (which he called 'The Dialogue of Counsel'), that is, the bulk of Book I as well as the short conclusion later in London. This means that the unmediated monologue on the imaginary ideal community was written first; which was placed within the qualifying context afterwards. Hexter's conclusion is that, in this way, More managed to communicate fairly radical ideas without the danger of exposing himself to direct criticism while his own standpoint was made successfully indeterminable, but his real mouthpiece, as the order of composition suggests, is Raphael.

This is an attractive conclusion, but by no means the only one possible. The fact (provided that we accept it for one) that More felt it important to insert 'The Dialogue of Counsel' before B.II does not necessarily mean that his only legitimate brainchild is B.II and the whole of B.I serves exclusively evasive purposes. The passion and the eloquence of the argument gives one the impression that More, the author, had been turning these problems over and over in his mind for some time and the dialogue represents his own inner torment. Several critics have suggested that, after the successful embassy to the Netherlands in 1515 which also served as a fictitious background to his work, More got within reach of royal service but he harboured serious doubts about accepting such a position and this is what prompted 'The Dialogue of Counsel'. If we accept this idea, however, then - in the light of More's ultimate decision and subsequent prominent political career - we are forced to conclude that, in More's mind, 'More' emerged victorious over Raphael, pragmatic considerations triumphed over idealistic principles. In that case, More may well have wondered during his last days in the Tower awaiting his execution for treason that Raphael was right after all: philosophers, no matter how good wrestlers they are, should keep away from monarchs as much as possible if they do not want to lose their head and their hair.

Utopia has become known to us in its final ambiguous and complex form; any balanced approach to the subsequent history of the concept of utopia should, as much as possible, bear all the implications of this in mind.

${ }^{27}$ See Hexter. 


\section{CONCLUSION}

More's Utopia stands at the crossroads of European culture, where the paths of the classical, the medieval and the Renaissance traditions meet, and it shows a different face to travellers approaching it from the various directions. Ancient models and recent discoveries, traditional thought and novel ideas, serious intention and mocking irony, severe criticism and jeu d'esprit - these are all present in More's universe and this is the reason why Utopia, just like its 'spiritual child', the concept of utopia, resists one-sided approaches and sweeping generalizations. Philosophy, literature and social reform all intermingle in a satirical composition, which must have appeared quite natural and self-explanatory for a Renaissance humanist-artist-lawyer-politician; he probably would not have understood the strict later separation of these disciplines, largely the result of the compartmentalization efforts of the eighteenth and nineteenth centuries, the age of reason and scientism. Bearing this complexity in mind, one is justified to see the subsequent development of utopia as a step-by-step realization of all the potential layers present in a nascent state in More's great pioneering work.

\section{BIBLIOGRAPHY}

More, Thomas: Utopia transl. by Paul Turner; Harmondsworth: Penguin, 1965

More, Thomas: Utopia (facsimile of the 1516 Louvain edition), Menston, Yorkshire: Schoiar Press, 1971

Adams, Hazard ed: Critical Theory since Plato, New York: Harcourt, 1965

Branham, R. Bracht: 'Utopian Laughter: Lucian and Thomas More', in: Keen-Kinney

Chambers, R.W.: Thomas More, Harmondsworth: Penguin, 1963 (1st ed.: 19.35)

Davis, J.C.: Utopia and the Ideal Society. A Study of English Utopian Writing 1516-1700, Cambridge: Cambridge University Press, 1981

Duhamel, P. Albert: 'Medievalism in More's Utopiad, in: Marc'hadour-Sylvester, 234-250

Elliott, Robert C.: The Shape of Utopia. Studies in a Literary Genre, Chicago: University of Chicago Press, 1970 
Frye, Northrop: 'Varieties of Literary Utopias', in: The Stubborn Structure. Essays on Criticism and Society, Ithaca NY: Cornell University Press, 1970, 109-134 (1st publ.: 1965)

Gibson, R.W.: Sir Thomas More: A Preliminary Bibliography of His Works and of Moreana to the Year 1750, New Haven: Yale University Press, 1961

Horace: "Art of Poetry" in: Adams 24-32

Hexter, J.H.: More's Utopia: The Biography of an Idea, Princeton, NJ: Princeton University Press, 1952

Kautsky, Karl: Thomas More und Seine Utopie, Offenbach a.M.: Bollwerk Verlag, 1947 (1e Ausgabe 1888)

Keen, R. - Kinney, D. eds: Thomas More and the Classics, Moreana, No. 86: July 1985

Lewis, C.S.: English Literature in the Sixteenth Century Excluding Drama, The Oxford History of English Literature, vol. III. Oxford: Clarendon Press, 1954

Logan, George M.: The Meaning of More's Utopia, Princeton NJ: Princeton University Press, 1983

Mannheim, Karl: Ideology and Utopia. An Introduction to the Sociology of Knowledge, London: Routledge \& Kegan Paul, 1972 (first German ed.: 1929, first English ed.: 1936)

Manuel, Frank E. - Manuel, Fritzie P.: Utopian Thought in the Western World, Oxford: Blackwell, 1979

Marc'hadour, G.P. - Sylvester, R.S.: Essential Articles for the Study of Thomas More, Hamden CT: Archon Books, 1977

Marx, Karl - Engels, Friedrich: The Communist Manifesto, New York: Pathfinder Press, 1980 (1st ed.: 1848)

McCutcheon, Elizabeth: 'Denying the Contrary: More's Use of Litotes in Utopia', in: Marc'hadour-Sylvester (1977) 263-274

McCutcheon, Elizabeth: 'More's Utopia and Cicero's Paradoxa Stoicorum' in: Keen Kinney (1985)

Molnar, Thomas: Utopia: the Perennial Heresy, New York: Sheed and Ward, 1967

Sidney, Sir Philip: Sidney's Apologie for Poetrie, ed. Churton Collins, Oxford: Clarendon ?ress, 1955 